\title{
A CONFIRMATION OF VALIDITY OF EDUCATIONAL ATTAINMENT AS A MEASURE OF INTELLIGENCE IN DIFFERENT GEOGRAPHICAL AREAS
}

\author{
E.V. CHMYKHOVA ${ }^{\mathrm{a}}$, D.G. DAVYDOV ${ }^{\mathrm{b}}$, A.A. GRIGORIEV ${ }^{\mathrm{c}}$, \\ M.S. ZIRENKO ${ }^{\mathrm{d}}$, R. LYNN ${ }^{\mathrm{e}}$
}

${ }^{a}$ Modern University for the Humanities, 32/4 Nizhegorodskaya Str., Moscow, 109029, Russian Federation

${ }^{b}$ Moscow City Center of Psychology and Pedagogy, 12/2 Yeseninskiy Blvd., Moscowe, 109443, Russian Federation

'Institute of Psychology of Russian Academy of Sciences, 13 Yaroslavskaya Str., Moscow, 129366, Russian Federation

${ }^{d}$ Lomonosov Moscow State University, 1 Leninskiye Gory, Moscow, 119991, Russian Federation

${ }^{e}$ University of Ulster, Coleraine, Northern Ireland, BS52 1SA, United Kingdom

\begin{abstract}
The validity of regional educational attainments as a measure of intelligence in different regions was estimated using a set of 29 regions from the Russian Federation. Educational attainments were the average scores obtained in the Unified State Exam 2014 by persons who were accepted in state universities and institutions for tertiary education in regions of the Russian Federation in the year 2014. Regional intelligence was assessed using samples aged 17-50 years. The size of the samples was from 28 to 365 participants (mean 154.8). In total 4,645 participants from 101 settlements of Russia were involved. The participants were tested with the Raven's Standard Progressive Matrices, a 20 minute time limitation was applied. Besides, data based on nine additional variables was used. These variables were the rate of crime per 100,000, the rate of fertility (birthrate), the rate of infant mortality, urbanization, net migration, per capita income in roubles (all for the year 2012), the latitude and longitude of the geographical mid-point of the regions, and the percentage of ethnic Russians. While the correlation of educational attainments with the measurements of intelligence in the regions was low (0.10), the functional closeness of these two measures, as estimated by correlating them with additional variables, was high enough (the correlation of the two vectors of correlations was $0.74, p<0.05$ ). This confirms the validity of regional educational attainments as a measure of regional intelligence. The low direct correlation of educational attainments with the measurements of intelligence can be explained by the inaccuracy of both measurements.
\end{abstract}

Keywords: intelligence, educational attainment, regional IQ.

S. Kanazawa (2006) was the first to attempt to show the relationship between regional IQs and indices of wealth of provinces (in states of the US). His research was based on the study of R. Lynn and T. Vanhanen who

This article was prepared with the support of an RSF grant project №14-18-03773. 
demonstrated such relationships on the country level. Unlike Lynn and Vanhanen, who used direct measurements of IQ in countries ${ }^{1}$, Kanazawa used the educational attainment of states as an index of state intelligence. He obtained not high but significant correlations between his index of state intelligence and measures of state wealth.

M.A. McDaniel (2006b) criticized Kanazawa's choice of the measure for educational attainment. He himself used another measure of educational attainment for estimating state IQs in states of the USA and showed the relationship between his estimates and a number of variables (see McDaniel, 2006a). McDaniel's estimates were used in the following studies (Pesta, McDaniel, \& Bertsch, 2010; Reeve \& Basalik, 2011).

To our knowledge, the use of educational attainments of states of the USA as an estimate of state IQ does not stand up to scrutiny. However, using the educational attainments of Italian provinces as an estimate of province IQ by R. Lynn (2010) conformed to the requirements (Felice \& Giugliano, 2011). The reviewers contended that the differences in measures of educational attainment that Lynn had used may have been affected by a number of factors beyond IQ. In contradiction to this critical objection, D.I. Templer (2012) has shown the validity of Lynn's estimates of IQ for Italian provinces: he reported a correlation between Lynn's estimates and direct measurements of the province IQs of 0.91 .

Although the use of indices of educational attainment as a measure of regional IQs for the Italian provinces appeared to be justified, this case points to vulnerability of educational attainments as a measure of regional IQ: their validity may be questioned. On the other hand, educational attainments usually have some advantages that psychological measurements often lack: they are usually large scale, sometimes involving whole populations; they proceed at the same time and sometimes regularly. This makes them rather attractive indices of regional IQ. In addition, we have successful precedents of using educational attainment as a measure of regional IQ, which encourages their further use in such a way. Nevertheless, validity of educational attainment as a measure of regional IQ should be controlled, if possible, in each particular case.

Grigoriev et al. (2016) adopted the average scores obtained in the Unified State Exam 2014 by persons who were accepted in state universities and institutions for tertiary education in regions of the Russian Federation in the year 2014 as proxies for average levels of intelligence. The validity of these estimates was confirmed by their correlations with a number of socio-economic variables. In the present paper we further confirm their validity by comparing them with direct measurements of regional IQs.

\section{Method}

\section{IQ measurements}

Data was collected in 2005-2006.

${ }^{1}$ Later Lynn \& Meisenberg (2010) and Lynn \& Vanhanen (2012) used a composite index of intelligence in a country. This index aggregates direct measurements and educational attainment. 


\section{Participants}

Intelligence was assessed from samples aged 17-50 years in 29 regions of the Russian Federation. The data for Moscow was drawn from the city itself and the Moscow Region. The size of the samples was from 28 to 365 participants (mean 154.8). In total 4,645 participants from 101 settlements of Russia were involved in the present study (44.0 percent of males, mean age 31.3).

\section{Procedure}

The participants were tested with the Raven's Standard Progressive Matrices (SPM). The test was administered individually or in small groups (up to 20 persons). A 20 minute time limitation was used. The testing was carried out in the presence of an examiner.

The samples and procedure are described in detail in (Davydov \& Chmykhova, 2016).

\section{Educational attainment}

Educational attainments for 29 regions were taken from Grigoriev et al. (2016). These are scores obtained in the Unified State Exam 2014 by persons who were accepted in state universities and institutions for tertiary education in regions of the Russian Federation in the year 2014. In Grigoriev et al. (2016), these scores for 79 regions were transformed to standard EQs (Educational Quotients, an analog of conventional IQs), with a mean of 100 and a standard deviation of 15 .

\section{Other variables}

Data on other variables for 29 regions was taken from Grigoriev et al. (2016). The variables were the rate of crime per 100,000 , the rate of fertility (birthrate), the rate of infant mortality, urbanization, net migration, per capita income in roubles (all for the year 2012), the latitude and longitude of the geographical mid-point of the regions, and the percentage of ethnic Russians.

\section{Results and discussion}

Data for 29 regions of the Russian Federation on all 11 variables is given in Table 1. Table 2 presents the product-moment correlations for the variables.

The correlation between regional intelligence as measured with SPM and EQ is low (0.10). The most plausible explanation of this is that both measures are not very accurate. EQs characterize only part of school students in the regions, namely persons accepted in state universities and institutions for tertiary education, they do not account for the prestige of universities in a region. On the other hand, samples in the SPM study were sometimes rather small and probably biased. This may reduce the direct correlation between two measures. However, we can use a method of estimating correspondence between these two variables that is more sensitive than correlating them directly.

Such a more sensitive method might be presented by correlating the vectors of correlations of two variables (whose correspondence one would like to estimate), 
Table 1

Average levels of intelligence in regions as measured with SPM, EQs, criminality, fertility, infant mortality, urbanization, net migration, latitude, longitude, percentage of Russians and per capita income for 29 regions from the Russian Federation

\begin{tabular}{|c|c|c|c|c|c|c|c|c|c|c|c|}
\hline Region & SPM & EQ & Crim & Fert & IM & Urb & Migr & Lat & Long & \% Rus & Inc \\
\hline Altai & 44.62 & 101 & 1,752 & 13.7 & 10.1 & 55.5 & -26 & 52.5 & 83.0 & 92.3 & 13,629 \\
\hline Bashkortos & 45.68 & 99 & 1,610 & 1.6 & 7.9 & 61.1 & -22 & 54.0 & 56.5 & 35.1 & 21,259 \\
\hline Belgorod & 45.89 & 100 & 968 & 11.6 & 7.1 & 66.6 & 56 & 50.5 & 37.5 & 91.7 & 21,563 \\
\hline Chelyabinsk & 41.74 & 98 & 2,026 & 14.4 & 8.6 & 82.2 & 13 & 54.0 & 60.5 & 81.4 & 19,763 \\
\hline Kaliningrad & 39.22 & 103 & 1,582 & 12.4 & 5.6 & 77.5 & 92 & 54.5 & 21.5 & 82.0 & 19,371 \\
\hline Kalmykiya & .64 & 32 & 1,311 & 15.0 & 7.7 & 44.7 & 138 & 46.5 & 5.5 & 29.6 & 0,184 \\
\hline Kamchatka & 44.98 & 86 & 1,663 & 13.1 & 11.3 & 77.1 & -2 & 57.0 & 160.0 & 78.4 & 31,482 \\
\hline Karachay-Cl & 38.75 & 86 & 777 & 13.7 & 10.6 & 42.9 & -99 & 44.0 & 41.5 & 31.4 & 13,354 \\
\hline Karelia & 44.26 & 101 & 1,799 & 12.6 & 7.6 & 78.8 & -15 & 63.5 & 33.0 & 78.9 & 20,037 \\
\hline Khakassiya & 31.18 & 98 & 2,073 & 16.0 & 12.9 & 67.7 & -10 & 53.5 & 90.0 & 80.3 & 15,991 \\
\hline Kostroma & 42.64 & 50 & 1,265 & 12.9 & 7.8 & 70.5 & -11 & 58.5 & 44.0 & 93.2 & 15,808 \\
\hline Krasnoyarsk & 41.04 & 98 & 2,061 & 14.5 & 9.7 & 76.6 & 13 & 65.0 & 96.0 & 88.1 & 22,138 \\
\hline $\begin{array}{l}\text { The City of Moscow } \\
\text { and the Moscow Region }\end{array}$ & 42.26 & 110 & 1,531 & 11.5 & 7.8 & 92.4 & 123 & 55.5 & 37.5 & 86.7 & 41,613 \\
\hline North Ossetiya & 38.14 & 00 & 886 & 15.3 & 11.6 & 63.9 & -87 & 43.0 & 44.5 & 20.6 & 16,185 \\
\hline Novosibirsk & 41.27 & 106 & 1,902 & 13.9 & 8.4 & 77.9 & 80 & 55.0 & 80.0 & 88.7 & 20,637 \\
\hline Orenburg & 44.91 & 100 & 1,417 & 14.8 & 9.7 & 59.7 & -44 & 52.0 & 56.0 & 74.7 & 16,539 \\
\hline Oryol & 43.81 & 93 & 1,699 & 11.2 & 10.5 & 65.8 & -18 & 52.5 & 36.5 & 93.9 & 16,762 \\
\hline Perm & 41.26 & 105 & 2,441 & 14.8 & 8.5 & 75.1 & 7 & 59.0 & 56.0 & 832 & 23,270 \\
\hline Pskov & 42.31 & 103 & 1,567 & 11.1 & 10.0 & 70.3 & 4 & 57.0 & 29.5 & 915 & 16,412 \\
\hline Samara & 42.91 & 101 & 1,884 & 12.1 & 7.0 & 80.3 & 16 & 53.5 & 50.5 & 823 & 24,683 \\
\hline Saratov & 44.28 & 99 & 1,146 & 11.4 & 7.0 & 74.8 & 7 & 51.5 & 46.0 & 853 & 14,243 \\
\hline Smolensk & 48.56 & 102 & 1,737 & 10.5 & 9.6 & 72.5 & 8 & 55.0 & 33.0 & 907 & 18,250 \\
\hline Sverdlovsk & 37.71 & 106 & 1,659 & 14.3 & 7.4 & 84.1 & 16 & 58.0 & 62.0 & 857 & 27,709 \\
\hline Tambov & 45.25 & 95 & 1,087 & 9.7 & 4.1 & 59.1 & 2 & 52.5 & 41.5 & 945 & 17,470 \\
\hline Tatarstan & 43.37 & 104 & 1,353 & 14.5 & 6.4 & 75.9 & 26 & 55.5 & 51.0 & 396 & 24,010 \\
\hline Vladimir & 43.79 & 98 & 1,525 & 11.5 & 7.8 & 77.6 & -20 & 56.0 & 40.5 & 893 & 16,136 \\
\hline Volgograd & 45.81 & 96 & 1,512 & 11.7 & 11.1 & 76.3 & -27 & 49.5 & 44.5 & 885 & 16,066 \\
\hline Vologda & 41.12 & 93 & 1,990 & 14.0 & 8.4 & 71.3 & -9 & 60.0 & 41.5 & 925 & 18,125 \\
\hline Voronezh & 41.53 & 100 & 1,188 & 10.9 & 6.6 & 66.3 & 43 & 51.0 & 40.0 & 910 & 18,885 \\
\hline
\end{tabular}

Note. SPM - Standard Progressive Matrices; EQ - Regional EQ 2014; Crim - Criminality 2012; Fert - Fertility 2012; IM - Infant Mortality 2012; Urb - Urbanization 2012; Migr - Migration 2012; Lat - Lalitude; Long - Longitude; \% Rus - Percentage of Russians in a region; Inc - Income 2012. 


\section{Correlations for the variables}

\begin{tabular}{|l|r|r|r|r|r|r|r|l|l|l|}
\hline & SPM & EQ & Crim & Fert & IM & Urb & Migr & Lat & Long & \% Rus \\
\hline EQ & 0.10 & & & & & & & & & \\
\hline Crim & -0.14 & 0.40 & & & & & & & & \\
\hline Fert & -0.57 & -0.16 & 0.29 & & & & & & & \\
\hline IM & -0.27 & -0.41 & 0.19 & 0.39 & & & & & & \\
\hline Urb & 0.04 & 0.56 & 0.47 & -0.17 & -0.16 & & & & & \\
\hline Migr & 0.09 & 0.71 & 0.27 & -0.36 & -0.40 & 0.73 & & & & \\
\hline Lat & 0.10 & 0.46 & 0.67 & -0.01 & -0.17 & 0.60 & 0.45 & & & \\
\hline Long & -0.12 & -0.23 & 0.34 & 0.41 & 0.43 & 0.08 & -0.03 & 0.21 & & \\
\hline \% Rus & 0.23 & 0.45 & 0.40 & -0.54 & -0.14 & 0.49 & 0.58 & 0.53 & 0.03 & \\
\hline Inc & 0.05 & 0.42 & 0.25 & -0.06 & -0.15 & 0.69 & 0.65 & 0.39 & 0.28 & 0.17 \\
\hline
\end{tabular}

Note. SPM - Standard Progressive Matrices; EQ - Regional EQ 2014; Crim - Criminality 2012; Fert - Fertility 2012; IM - Infant Mortality 2012; Urb - Urbanization 2012; Migr - Migration 2012; Lat - Lalitude; Long - Longitude; \% Rus - Percentage of Russians in a region; Inc - Income 2012.

with some third variables. High correlation between such vectors points to similar structures of relationships of these two variables, and to their functional closeness. This methodology follows the method of correlated vectors developed by A. Jensen to determine the role of the general factor of intelligence (g) in correlations of various mental tests with an external variable (see, for example, Rushton \& Jensen, 2005). Namely, we estimated the rela- tionship between the vector of the correlations of measured intelligence with nine variables (see the second column of Table 2) and the vector of the correlations of EQ with the same variables (see the third column of Table 2). The correlation between the two vectors is $0.74(p<0.05)$. This points to functional closeness of measures of regional intelligence as measured with SPM and EQ and, hence, confirms their correspondence.

\section{References}

Davydov, D. G., \& Chmykhova, E. V. (2016). Administration of the Raven's Standard Progressive Matrices with a time limit. Voprosy Psikhologii, 4, 129-139.

Felice, E., \& Giugliano, F. (2011). Myth and reality: A response to Lynn on the determinants of Italy's North-South imbalances. Intelligence, 39(1), 1-6.

Grigoriev, A., Ushakov, D., Valueva, E., Zirenko, M., \& Lynn, R. (2016). Differences in educational attainment, socio-economic variables and geographical location across 79 provinces of the Russian Federation. Intelligence, 58(1), 14-17. 
Kanazawa, S. (2006). IQ and the wealth of states. Intelligence, 34(6), 593-600.

Lynn, R. (2010). In Italy, North-South differences in IQ predict differences in income, education, infant mortality, stature, and literacy. Intelligence, 38(1), 93-100.

Lynn, R., \& Meisenberg, G. (2010). National IQs calculated and validated for 108 nations. Intelligence, 38(4), 353-360.

Lynn, R., \& Vanhanen, T. (2012). Intelligence: A unifying construct for the social sciences. London: Ulster Institute for Social Research.

McDaniel, M. A. (2006a). Estimating state IQ: Measurement challenges and preliminary correlates. Intelligence, 34(6), 607-619.

McDaniel, M. A. (2006b). State preferences for the ACT versus SAT complicates inferences about SAT-derived IQ estimates: A comment on Kanazawa (2006). Intelligence, 34(6), 601-606.

Pesta, B. J., McDaniel, M. A., \& Bertsch, S. (2010). Toward an index of well-being for the fifty U.S. states. Intelligence, 38(1), 160-168.

Reeve, C. L., \& Basalik, D. (2011). A state level investigation of the association among intellectual capital, religiosity and reproductive health. Intelligence, 39(1), 64-73.

Rushton, J. P., \& Jensen, A. R. (2005). Thirty years of research on race differences in cognitive ability. Psychology, Public Policy, and Law, 11(2), 235-294.

Templer, D. I. (2012). Biological correlates of Northern-Southern Italy differences in IQ. Intelligence, 40(5), 511-517.

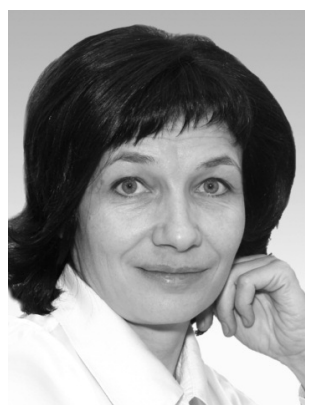

Ekaterina V. Chmykhova - head of the Department of Research and Innovation, Modern University for the Humanities, Ph.D.

Research area: psychology of education, sociology of education, cognitive abilities, intellect, demography of education, psychology of university education.

E-mail: echmyhova@campus.muh.ru

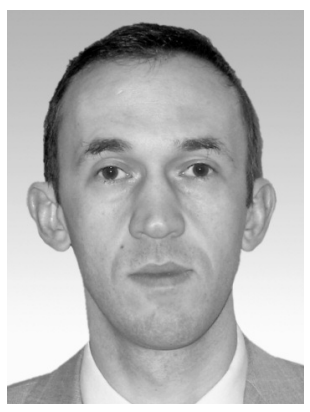

Denis G. Davydov - head of the Laboratory of Adolescent Socialization, Moscow City Center of Psychology and Pedagogy, Ph.D. Research area: cognitive abilities, intelligence, search activity, psychology of education.

E-mail: davydovdg@edu.mos.ru 


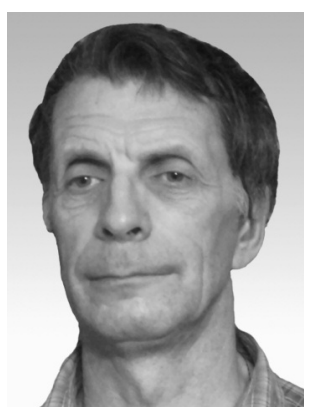

Andrei A. Grigoriev - chief research fellow, Institute of Psychology of Russian Academy of Sciences, D.Sc., associate professor.

Research area: intelligence, individual differences, psycholinguistics.

E-mail: andrey4002775@yandex.ru

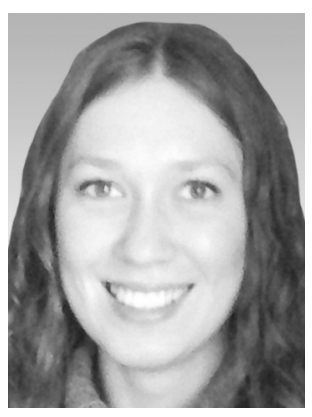

Maria S. Zirenko - postgraduate student, Department of Psychology, Lomonosov Moscow State University.

Research area: intelligence, implicit theories of intelligence, individual differences in education.

E-mail: mzirenko@inbox.ru

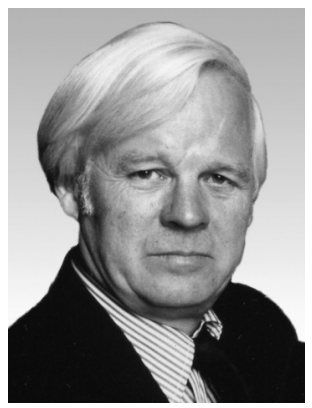

Lynn Richard - emeritus professor, University of Ulster, Ph.D.

Research area: intelligence, sex differences, race differences, eugenics.

E-mail: lynnr540@aol.com

\section{Подтверждение валидности образовательных достижений как показателя регионального интеллекта}

\section{Е.В. Чмыхова ${ }^{a}$, Д.Г. Давыдов ${ }^{\mathrm{b}}$, А.А. Григорьев ${ }^{\mathrm{c}}$, М.С. Зиренко $^{\mathrm{d}}$, Р. Линн}

${ }^{a}$ ЧОУ ВО Современная гуманитарная академия, 109029, Россия, Москва, ул. Нижегородская, д. 32 , к. 4

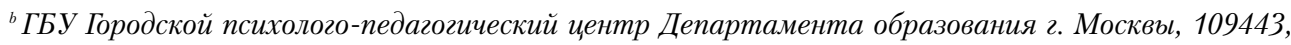
Россия, Москва, Есенинский бульвар, д. 12, к. 2

${ }^{c}$ ФГБУН Институт психологии РАН, 129366, Россия, Москва, ул. Ярославская, д. 13, к. 1

${ }^{d}$ Московский государственныий университет имени М.В. Ломоносова, 119991, Россия, Москва, Ленинские горы, Ә. 1

е Университет Ольстера, Coleraine, Northern Ireland, BS52 1SA, Великобритания 


\section{Резюме}

Валидность образовательных достижений регионов как показателя регионального интеллекта была оценена на множестве 29 регионов Российской Федерации. Региональные образовательные достижения представляли собой средние баллы, полученные на Едином государственном экзамене в 2014 г. лицами, принятыми в бюджетные вузыы регионов Российской Федерации в 2014 г. Региональный интеллект оценивался на выборках респондентов в возрасте 17-50 лет. Размер выборок варьировал от 28 до 365 (в среднем 154.8). Всего 4645 респондентов из 101 населенного пункта России приняли участие в исследовании. Измерение интеллекта проводилось с помощью теста «Стандартные прогрессивные матрицы Равена» с 20-минутным ограничением времени тестирования. Кроме того, были использованы данные по девяти дополнительным переменным. Этими переменными были число зарегистрированных преступлений на 100000 человек населения, число родившихся на 1000 человек населения, младенческая смертность, доля городского населения, миграционное сальдо, доход на душу населения в рублях (все за 2012 г.), широта и долгота географического центра региона, доля этнических русских. В то время как корреляция образовательных достижений с измеренным интеллектом была низкой (0.10), функциональная близость этих двух показателей, оцененная путем коррелирования их с дополнительными переменными, была достаточно высокой (корреляция двух векторов корреляций составила 0.74; $p<0.05)$. Это подтверждает валидность образовательных достижений регионов как показателя регионального интеллекта. Низкое значение прямой корреляции образовательных достижений с измеренным интеллектом может быть объяснено неточностью обеих этих мер.

Ключевые слова: интеллект, образовательные достижения, региональный IQ.

Чмыхова Екатерина Витальевна - руководитель департамента науки и инноваций ЧОУ ВО Современная гуманитарная академия, кандидат социологических наук, доцент.

Сфера научных интересов: психология обучения, социология образования, когнитивные способности, интеллект, демография образования, психология высшей школы.

Контакты: echmyhova@campus.muh.ru

Давыдов Денис Геннадьевич - руководитель лаборатории проблем социализации подросткового возраста, ГБУ Городской психолого-педагогический центр Департамента образования г. Москвы, кандидат психологических наук.

Сфера научных интересов: когнитивные способности, интеллект, поисковая активность, психология обучения.

Контакты: davydovdg@edu.mos.ru

Григорьев Андрей Александрович - главный научный сотрудник, ФГБУН Институт психологии РАН, доктор филологических наук, доцент.

Сфера научных интересов: интеллект, индивидуальные различия, психолингвистика.

Контакты: andrey4002775@yandex.ru

Зиренко Мария Сергеевна - аспирант, факультет психологии Московского государственного университета имени М.В. Ломоносова.

Сфера научных интересов: интеллект, имплицитные теории интеллекта, индивидуальные различия в обучении.

Контакты: mzirenko@inbox.ru

Линн Ричард - почетный профессор, Университет Ольстера, Ph.D.

Сфера научных интересов: интеллект, половые различия, расовые различия, евгеника.

Контакты: lynnr540@aol.com 